\title{
Biopolymer films for food industries: properties, applications, and future aspects based on chitosan
}

\author{
Fakfan Luangapai ${ }^{1}$, Methavee Peanparkdee ${ }^{2}$, Satoshi Iwamoto ${ }^{1,2,3,{ }^{*}}$ \\ ${ }^{1}$ Department of Life Science and Chemistry, Graduate School of Natural Science and Technology, Gifu University, 1-1 Yanagido, Gifu \\ 501-1193, Japan. \\ ${ }^{2}$ Division of Science of Biological Resources, United Graduate School of Agricultural Science, Gifu University, 1-1 Yanagido, Gifu 501-1193, \\ Japan. \\ ${ }^{3}$ Department of Applied Life Science, Faculty of Applied Biological Science, Gifu University, 1-1 Yanagido, Gifu 501-1193, Japan.
}

\section{ABSTRACT}

Chitosan is an N-deacetylate derivative of chitin, which can be found in crustaceans, insects, and fungi. In several studies, chitosan is pursued to be applied as an optional biopolymeric material in food, agriculture, and pharmaceutical industries. Owing to its high commercially potential properties, including good film forming ability, physicochemical properties, antimicrobial activity and non-toxicity, chitosan has been widely used as an active material for formation of edible films. Chitosan based films can be manufactured for packaging, especially for edible food packaging. This is in accordance with green-consumption, which involves preference to materials derived from natural sources rather than synthetic substances. This manuscript provides an overview of the extensive research on chitosan properties, applications, and further aspect of chitosan based approach in food industries.

Keywords

Chitosan-based film, Hydrocolloid biopolymer, Edible film, Antimicrobial properties, Food application, Food industry.

\section{Introduction}

Food products undergo regular alteration by huge number of physical, chemical, and microbial factors during storage. The stability of the food components such as proteins, lipids, carbohydrates, and water changes caused by different environmental factors, processing conditions, and processing factors. To maintain quality of food products, food packaging has been used for not only reduces food spoilage, but also reinforces quality and extends shelf life of food product. Various food packaging materials have selected carefully to avoid undesired interactions in food since former time (Cha and Chinnan, 2004). Contrastingly, the world attention given on 'green consumption', which promotes minimal usage of food packaging material; synthetic and petroleum materials which harmful to global environment (Nurhayati and Agusman, 2011), thus, finding another material instead of synthetic or petroleum materials should be concerned. Various investigations are developed increasingly in the field of food packaging by using biopolymer obtained from natural sources such as whey, chitosan, gelatin and corn zein instead of synthesis material to further the concertation and to sustain world's environment.

The biopolymers have been investigated for their ability to retard moisture, oxygen, aromas, and solute transports, which can be obtained from many natural sources, such as waste products from fishing, agriculture or cattle farming, (Vieira et al., 2011). Biopolymeric substances are commonly derived from hydrocolloids (polysaccharide and protein) and lipids (Tharanathan, 2003), which provide different properties, such as antimicrobial effect, gas barrier, moisture barrier and biodegradable activity. Among the studies on biopolymer, chitosan serves as a promising option for its application in agriculture, food, and pharmaceutical industry. Chitosan shows as highly dominant due to its properties, such as physicochemical properties (good biocompatibility and biodegradability) and effective of antimicrobial activities on microorganism like fungi, yeasts, and bacteria, plus chitosan have been widely used in industries because its non-toxicity materials (Wu et al., 2005). These benefits of chitosan have been studied thoroughly year to year (Avila-Sosa et al., 2012; Leceta et al., 2013).

As mention previously, chitosan demonstrated a number of activities, hence, in this manuscript mainly highlight on the potential of chitosan in the way of biopolymer characteristic. Plus, the manuscript contended information of applications of chitosan and chitosan composited with substances and biopolymers also given future aspect in the field of food packaging.

\section{Biopolymer films}

Recently, biopolymers have gained more attention due to intimately to environment, renewable, inexpensive, biodegradable and high potential to be used as food packaging. Biopolymers are polymer obtained from agricultural product or animals. They are 
generated from natural sources like carbohydrate (cellulose, chitin, starch) and protein (corn zein, whey). Biopolymer materials from natural sources enhance sensory characteristics and extend shelf life of food products. Biopolymers from natural sources consist of macromolecules including proteins and polysaccharides, which play an important role in the improvement of food structure and stability. (Ai et al., 2015; Gao et al., 2017; Rhim and Ng, 2007).

\subsection{Protein based films}

Protein based films are produced by reaction of polymerization to associate amino acid unit, the different sources of protein film provided different properties of the films also intermolecular bonding at different positions (Ou et al., 2005). The protein films have been expanded for using in industrial for many years because they have excellent barrier properties for oxygen, carbon dioxide, and volatile compounds (Cuq et al.,1998; Limpan et al., 2010). However, the films have limitations, for example, they shown poor water vapor barrier characteristics, which is considered as a major limitation for using of protein films in the field of packaging as shows in Table 1 (Gennadios et al., 1994).

Table 1 Properties and limitations of proteins

\begin{tabular}{|c|c|c|}
\hline Hydrocolloids & Properties & References \\
\hline \multirow[t]{2}{*}{ Gelatin } & $\begin{array}{l}\text { Advantages } \\
\text { - Barrier to oxygen, light } \\
\text { - Prevent dehydration and lipid oxidation } \\
\text { - High puncture strength and low puncture deformation } \\
\text { - High water vapor permeability }\end{array}$ & $\begin{array}{l}\text { Jongjareonrak et al. (2008) } \\
\text { Sobral et al. (2001) }\end{array}$ \\
\hline & $\begin{array}{l}\text { Limitations } \\
\text { - High hygroscopic } \\
\text { - Insoluble in alcohol and non-polar solvents }\end{array}$ & $\begin{array}{l}\text { Nur et al. (2014) } \\
\text { Jamilah and Harvinder (2002) }\end{array}$ \\
\hline \multirow[t]{2}{*}{ Corn zein } & $\begin{array}{l}\text { Advantages } \\
\text { - Good tensile and water-barrier properties } \\
\text { - Grease and oil resistance } \\
\text { - Biodegradability and biocompatibility } \\
\end{array}$ & $\begin{array}{l}\text { Shukla and Cheryan (2001) } \\
\text { Ghanbarzadeh et al. (2007) } \\
\text { Lou and Wang (2014) }\end{array}$ \\
\hline & $\begin{array}{l}\text { Limitations } \\
\text { - Tough and brittle } \\
\text { - Less solubility }\end{array}$ & $\begin{array}{l}\text { Cuq et al. (1998) } \\
\text { Biswas et al. (2009) }\end{array}$ \\
\hline \multirow[t]{2}{*}{ Whey } & $\begin{array}{l}\text { Advantages } \\
\text { - Transparent and flexible } \\
\text { - Excellent oxygen and aroma barrier }\end{array}$ & Miller et al. (1997) \\
\hline & $\begin{array}{l}\text { Limitations } \\
\text { - Poor moisture barriers } \\
\text { - Brittle and stiff film }\end{array}$ & $\begin{array}{l}\text { Shellhammer and Krochta (1997) } \\
\text { McHugh and Krochta (1994) }\end{array}$ \\
\hline
\end{tabular}

In addition, the protein based biopolymers and their complexes with other polymers are utilized in many of applications. In Table 2 exhibits protein based biopolymer application which mainly focused on gelatin, corn zein and whey.

Table 2 Application of protein-based films as food packaging

\begin{tabular}{|l|l|l|l|}
\hline Hydrocolloid & Composite & Abilities & References \\
\hline Gelatin & - Casein & $\begin{array}{l}\text { Great elongation values and } \\
\text { less water vapor } \\
\text { permeability. } \\
\text { Slower release of the drug or } \\
\text { no releasing. }\end{array}$ & $\begin{array}{l}\text { Chambi and Grosso (2006) } \\
\text { Marques (2014) }\end{array}$ \\
\hline Corn zein & - None & $\begin{array}{l}\text { Excellent barrier and } \\
\text { biodegradability } \\
\text { Suppression of swelling of } \\
\text { pectin and beads for } \\
\text { colon-specific drug delivery }\end{array}$ & $\begin{array}{l}\text { Ozcalik and Tihminlioglu } \\
\text { Liu et al. (2006) }\end{array}$ \\
\hline Whey & - None & $\begin{array}{l}\text { Anti-browning effect } \\
\text { Transparent and low water } \\
\text { vapor permeability. }\end{array}$ & $\begin{array}{l}\text { Perez Gago et al. (2003) } \\
\text { Qazanfarzadeh and Kadivar } \\
\text { (2016) }\end{array}$ \\
\hline
\end{tabular}




\subsection{Polysaccharide based films}

The films of polysaccharides or in another word called carbohydrate based films (starch, alginate and chitosan) exhibited good gas barrier properties (Wang et al., 2007). Linear structure of some of these polysaccharides provide films, which are tough, flexible, good film-forming properties, and can be applied with barriers against oils and lipids. However, the films have poor water vapor barriers and low in elasticity due to their hydrophilic nature as shown in Table 3.

Moreover, polysaccharide-based films and their composites enhance film forming properties, which are regularly useful in various food applications. Several studies reported that polysaccharide based films demonstrated high ability including water vapor resistance, higher solubility, tensile strength, and elongation, shows in Table 4.

Amid the reviewed of the protein and polysaccharide-based biopolymers, within this manuscript chitosan films demonstrate capability because its properties present remarkable antimicrobial activity, gas barrier, and physicochemical properties in food preservation this is one of the reasons that chitosan is becoming mostly used as an edible biopolymer in food industry (Ilium, 1998; Mitani et al., 1995).

Table 3 Properties and limitations of polysaccharides

\begin{tabular}{|c|c|c|}
\hline Hydrocolloid & Properties & References \\
\hline \multirow[t]{2}{*}{$\begin{array}{l}\text { Starch } \\
\text { (all derivatives) }\end{array}$} & $\begin{array}{l}\text { Advantages } \\
\text { - Excellent oxygen barriers and low solubility } \\
\text { - Transparent, odorless, tasteless, and colorless. }\end{array}$ & $\begin{array}{l}\text { Jiménez et al. (2012). } \\
\text { Mali et al. (2004). }\end{array}$ \\
\hline & $\begin{array}{l}\text { Limitations } \\
\text { - Brittle and easy to break }\end{array}$ & $\begin{array}{l}\text { Jiménez et al. (2012). } \\
\text { Mali et al. (2004). }\end{array}$ \\
\hline \multirow[t]{2}{*}{ Alginate } & $\begin{array}{l}\text { Advantages } \\
\text { - Ability to react with polyvalent metal cations }\end{array}$ & Grant et al. (1973) \\
\hline & $\begin{array}{l}\text { Limitations } \\
\text { - Poor water resistance }\end{array}$ & Guilbert (1986) \\
\hline \multirow[t]{2}{*}{ Chitosan } & $\begin{array}{l}\text { Advantages } \\
\text { - Biocompatible polymer } \\
\text { - Excellent gas and aroma barrier properties } \\
\text { - Strong antimicrobial properties } \\
\text { - Bivalent minerals chelating ability }\end{array}$ & $\begin{array}{l}\text { Alexandre et al. (2016) } \\
\text { Darmadji and Izumimoto (1994) } \\
\text { Jo et al. (2001) } \\
\text { Yuan et al. (2016) } \\
\text { Chen et al. (2002) }\end{array}$ \\
\hline & $\begin{array}{l}\text { Limitations } \\
\text { - Less water resistance }\end{array}$ & Suyatma et al. (2004) \\
\hline
\end{tabular}

Table 4 Application of polysaccharide-based films as food packaging

\begin{tabular}{|c|c|c|c|}
\hline Hydrocolloids & Composites & Abilities & References \\
\hline $\begin{array}{l}\text { Starch } \\
\text { (all derivatives) }\end{array}$ & $\begin{array}{l}\text { - Carnauba wax edible } \\
\text { - Levan }\end{array}$ & $\begin{array}{l}\text { Decrease respiration rate and } \\
\text { increase water vapor resistance } \\
\text { Good compatibility with higher } \\
\text { solubility, tensile strength and } \\
\text { elongation and lower water } \\
\text { vapor permeability }\end{array}$ & $\begin{array}{l}\text { Chiumarelli and Hubinger (2012) } \\
\text { Mantovan et al. (2018) }\end{array}$ \\
\hline Alginate & - None & $\begin{array}{l}\text { Creating restructured foods } \\
\text { such as meat products, onion } \\
\text { rings and cocktail berries }\end{array}$ & Draget et al. (2016) \\
\hline Chitosan & $\begin{array}{l}\text { - Titanium dioxide nanocomposite } \\
\text { - Thyme oil }\end{array}$ & $\begin{array}{l}\text { Delayed the ripening process } \\
\text { and extend the storage life of } \\
\text { the tomato fruit } \\
\text { Antimicrobial and antioxidant } \\
\text { properties }\end{array}$ & $\begin{array}{l}\text { Kaewklin et al. (2018) } \\
\text { Altiok et al. (2010) }\end{array}$ \\
\hline
\end{tabular}

\section{Chitosan}

Chitin or poly ( $\beta(1-4)-\mathrm{N}$-acetyl-D-glucosamine) is one of the most abundant polysaccharides from natural sources. Chitosan is prepared from the chemical N-deacetylation of chitin, which can be found in crustaceans, insects, and fungi. It is composed of glucosamine and $\mathrm{N}$-acetyl glucosamine linked by $\beta 1 \rightarrow 4$ glucosidic bonds (Tiwary and Rana, 2010).

Chitosan exhibits semi crystalline polysaccharide, which cannot be soluble in neutral $\mathrm{pH}$, water but high concentration of organic acid (Murray and Dutcher, 2006). The potential of chitosan to act as a food preservative of natural origin has been widely reported on the basis of in vitro trials as well as through its direct application on real complex matrix foods (Durango et al., 2006). 
Additionally, chitosan is also used as an active material to form potential film in food industry, due to its antimicrobial efficiency (Zheng and Zhu, 2003). The antimicrobial mechanism of chitosan has not been completely clarified yet; however, several hypotheses have been demonstrated. One of the most possible hypotheses is the change in cell permeability due to interactions between the positively charged chitosan molecules and the negatively charged microbial cell membranes. The interaction leads to the leakage of proteinaceous and other intracellular substances (Chen et al., 1998). Several studies have reported that the antimicrobial properties depend on molecular weight and concentration of chitosan. The findings have been shown that low molecular weight of chitosan (less than $10 \mathrm{kDa}$ ) contribute higher antimicrobial potential compare to high molecular weight chitosan due to better solubility of lower molecular weight of chitosan (Uchiha et al., 1989). The lower molecular weight likely to solute in media easily than the higher molecular, the benefit of solubility make chitosan suitable binding with microorganism and shows inhibitory effect (Aider, 2010).

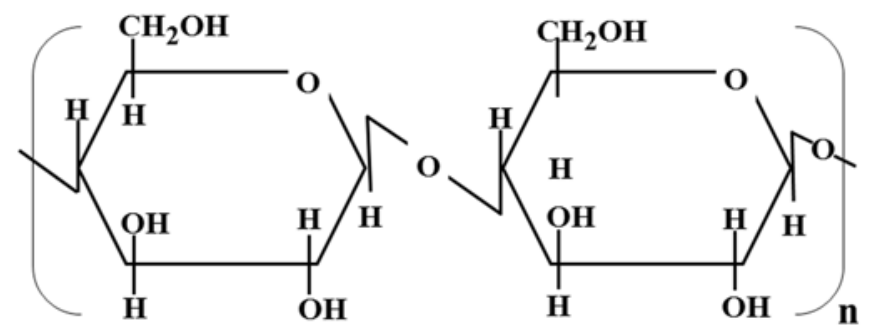

Cellulose

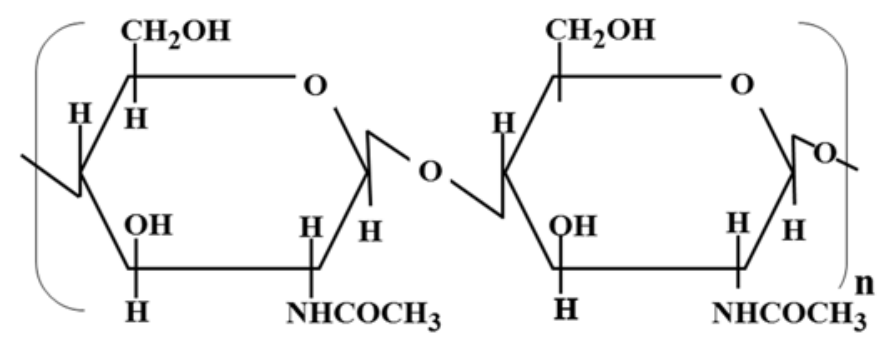

Chitin

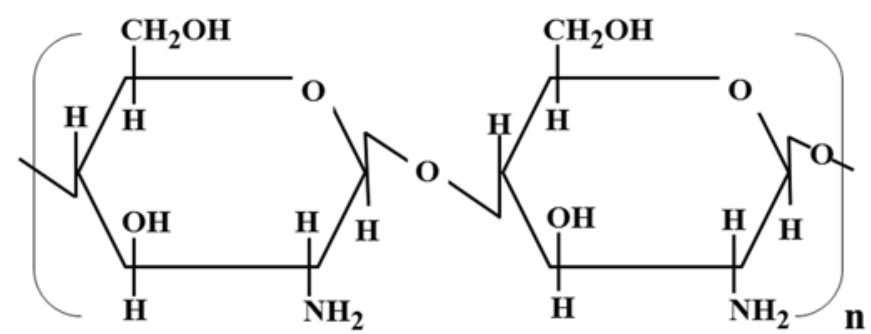

Chitosan

Fig.1 Cellulose, Chitin and Chitosan

Correspondingly, No et al. (2002) examined the antibacterial activities of 6 chitosan samples and 6 chitosan oligomers with different molecular weights (MW) against 4 Gram-negative (Escherichia coli, Pseudomonas fluorescens, Salmonella typhimurium, and Vibrio parahaemolyticus) and 7 Gram-positive bacteria (Listeria monocytogenes, Bacillus megaterium, B. cereus, Staphylococcus aureus, Lactobacillus plantarum, L. brevis, and L. bulgaricus). They revealed that chitosan significantly inhibited the growth of most bacteria tested; however, the inhibitory effects depend on molecular weight of chitosan and the type of bacterium. Moreover, chitosan mainly showed stronger bactericidal effects for gram-positive bacteria than for gram-negative bacteria.

The study by Ziani et al. (2009) investigated the antifungal properties of films and solutions based on chitosan with different molecular weight at varying concentrations. Surfactants were added to the formulation in order to improve their treatment efficiency. The antifungal activity was determined against three fungi, Aspergillus niger, Alternaria alternata and Rhizopus oryzae. The results indicated that the antifungal activity of the differential treatment depended on the type of fungus treated. The impact of the other parameters such as concentration, molecular weight and surfactant type on treatment were not important and their significance as 
treatment type and fungus sources.

\subsection{Chitosan Film}

Chitosan presents high potential as films with tough, flexible, and durable to extension characteristics. Chitosan films show great property, for instance, outstanding film forming also at dry condition chitosan shown gas and aroma barrier activities that appropriate to apply to food packaging (Dutta et al., 2009). The properties of the films rely on its physical characteristics, including molecular weight, degree of $\mathrm{N}$-acetylation, evaporation of solvent, and free amine regenerating mechanism (Casariego et al., 2009). The films can be manipulated for packaging, especially for edible food packaging. This is because the film provides great barrier properties of oxygen and carbon dioxide, besides having remarkable antimicrobial activities.

Nevertheless, chitosan films are not appropriate for some application due to their solubility in aqueous medium with small amount of organic acid such as acetic acid. Besides, chitosan films easily interact with humidity because they consists of hydrogen bonds which decrease efficiency of physicochemical of the films (Mujtaba et al., 2019). Several researchers attempt to overcome this drawback by using surface modification techniques, or combing them with other polymers and active substance such as moisture resistant polymer, plasticizers, and/or active ingredient. Combining chitosan film with another polymer can improve the stability of films by lessens melting temperature or increase temperature of glass transition (Rathke and Hudson, 1994; Zhang et al., 2002). In addition, adding active substance such as essential oil, antimicrobial agent, or antioxidant agent can be assembles advantages of each component to improve the antimicrobial and/or antioxidant properties of the films (Vargas et al., 2009).

\subsection{Composite Chitosan Films}

Indeed, the desirable properties of different materials may be combined to form composite films or multiplayer films, such as bilayer or emulsion films. There are several researches done on chitosan along with other biopolymer and active substance to further improve their properties of the films as shown in Table 5 (Coma et al., 2001; Ouattara et al., 2000; Pranoto et al., 2005).

Table 5 Ability of chitosan composite films

\begin{tabular}{|l|l|l|l|}
\hline Composites & Abilities & References & \\
\cline { 2 - 4 } & Starch & - High elongation & Thawien and Manjeet (2008) \\
\cline { 2 - 4 } & Gelatin & $\begin{array}{l}\text { - High barrier } \\
\text {-Improving mechanical } \\
\text { properties and microstructure } \\
\text { properties }\end{array}$ & Nagahama et al. (2009) \\
\cline { 2 - 4 } & Whey protein & - Antimicrobial properties & Ferreira et al. (2009) \\
\hline \multirow{7}{*}{ Active Substance } & Bergamot essential oil & $\begin{array}{l}\text { - Antimicrobial activity } \\
\text { against Penicillium italicum - } \\
\text { Improving the water vapour } \\
\text { barrier properties. }\end{array}$ & Silva et al. (2012) \\
\cline { 2 - 4 } & Eucalyptus oil nanoemulsion & $\begin{array}{l}\text { - Reduced moisture content } \\
\text { Antibacterial activity. }\end{array}$ & Sugumar et al. (2015) \\
\cline { 2 - 4 } & $\begin{array}{l}\text { Cinnamaldehyde } \\
\text { nanoemulsion }\end{array}$ & $\begin{array}{l}\text { Antimicrobial activity against } \\
\text { both bacteria and fungi. }\end{array}$ & Chen et al. (2016) \\
\hline
\end{tabular}

\subsection{Applications of chitosan}

Chitosan has been considered as a natural source biopolymer with antimicrobial activity and bivalent minerals chelating ability (Chen et al., 2002), which enhances its ability in the field of food and packaging industries. Many studies have investigated the applications of chitosan based films to improve quality and prolong the shelf life of food products. (Coma, 2008; Elsabee et al., 2008; Rabea et al., 2003)

Chien et al. (2007) manually treated sliced mango with aqueous solutions of $0 \%, 0.5 \%, 1 \%$ or $2 \%$ chitosan, in order to slower water loss, improve quality of sensory, increase soluble solid content (acidity and ascorbic acid content). Moreover, coating sliced mango with chitosan could also inhibit the growth of microorganism. In conclusion, applying a chitosan coating effectively prolongs its quality attributes and extends the shelf life of the sliced mango fruit.

Sathivel et al. (2007) used chitosan film for glazing skinless pink salmon filets to delay lipid oxidation in skinless pink salmon filets after eight months frozen storage. Since chitosan film served as a great barrier to oxygen, while having low WVP, chitosan coated filets had a higher thaw yield than that of the control (non-glazed). Moreover, a chitosan composite coating has been exani- 
mated by Maqbool et al. (2010). They combined Arabic gum and chitosan to control post-harvest anthracnose of banana using composite coating during and after cold storage. The result is that Arabic gum alone did not show any fungicidal effects while the combination of $1.0 \%$ chitosan with all tested Arabic gum concentrations had fungicidal effects.

Siripatrawan and Harte (2010) studied physical properties and antioxidant activity of an active film from chitosan incorporated with green tea extract (GTE). The results showed that chitosan incorporated with GTE develop properties of mechanical and water vapor barrier and enhanced polyphenolic content and antioxidant of the films so that chitosan film with GTE should be used as an active packaging.

Gómez-Estaca et al. (2010) prepared chitosan-gelatin films incorporated with several different essential oils. It was found that the films exhibited antibacterial property against 18 different bacterial strains, which included some important food pathogen and spoilage bacteria. In this study, clove essential oil showed the highest inhibitory effect, followed by rosemary and lavender, respectively. Chitosan with non-incorporating films did not show inhibitory zone in bacterial strains tested due to its natural characteristic. This effect of chitosan occurred without migration of active agents. Chitosan does not diffuse through the adjacent agar media in agar diffusion test method, beside only the direct contact with the active sites of chitosan being only inhibited (Coma et al., 2002).

Chitosan blended with cinnamon oil has also been used for the preservation of trout fish filet conducted by Ojagh et al. (2010). The samples prolong trout fillet shelf life through the 16 days storage time without markedly loss of texture, odor, color, or overall acceptability and without significant microbial growth. Meanwhile, the control samples had a shelf life of only 12 days. Therefore, chitosan coating together with cinnamon oil revealed to be an efficient method of prolonging the storage of fish for a longer period.

\section{Future Aspects}

According to the recent health trend, using nature resources, instead of synthetic or petroleum material are concerned. Biopolymer, especially chitosan has been increasingly used as biopolymer films. Chitosan provides antimicrobial activities and good film forming properties, however, it is highly sensitive to moisture (Suyatma et al., 2004). Thus, chitosan may not be proper when applied directly into food surface. Therefore, further research is needed to improve moisture sensitivity and strengthen the structure of the chitosan films.

Although, several researchers have tried to improve the properties of chitosan film by compositing with various hydrocolloids, plasticizers, essential oils, and antioxidant substances, some limitations of films production were still found. For example, Bonilla et al. (2018) examined active film of chitosan incorporated with eugenol and ginger essential oils for application in food packaging. The obtained film demonstrated a great antioxidant activity; however, water vapor permeability was still fairly high. Therefore, further development of edible antioxidant films to improve physical properties should be considered.

Furthermore, most of the experiments done in the field of food packaging of chitosan film have been carried out in small or laboratory scale. For this reason, some conditions remain untested or its actual volume of production cannot be validated. Hence, further study should be determined on a large industrial scale by using regular conditions. This would have more practical applications for the potential use of chitosan based film as food packaging in the food industries.

\section{REFERENCES}

Ai W, Fang Y, Xiang S, Yao, X, Nishinari K and Phillips O (2015) Protein/polysaccharide electrostatic complexes and their applications in stabilizing oil-in-water emulsions. J. Nutr. Sci. Vitaminol., 61: S168-S169.

Aider M (2010) Chitosan application for active bio-based films production and potential in the food industry: Review. LWT - Food Sci. Technol., 43: 837-842.

Alexandre C, Lourenço V, Bittante B, Moraes F and Sobral A (2016) Gelatin-based films reinforced with montmorillonite and activated with nanoemulsion of ginger essential oil for food packaging applications. Food Packaging Shelf, 10: 87-96.

Altiok D, Altiok E and Tihminlioglu F (2010). Physical, antibacterial and antioxidant properties of chitosan films incorporated with thyme oil for potential wound healing applications. J. Mater. Sci. Mater. Med., 21: 2227-2236.

Avila-Sosa R, Palou E, Munguía J, Nevárez-Moorillón V, Cruz N and López-Malo A (2012) Antifungal activity by vapor contact of essential oils added to amaranth, chitosan, or starch edible films. Int. J. Food Microbiol. 153: 66-72.

Biswas A, Selling W, Woods K and Evans K (2009) Surface modification of zein films. Ind. Crop. Prod., 30: 168-171.

Bonilla J, Poloni T, Lourenço V and Sobral A (2018) Antioxidant potential of eugenol and ginger essential oils with gelatin/chitosan films. Food Biosci., 23: 107-114.

Casariego A, Souza B, Cerqueira M, Teixeira J, Cruz L, Díaz R and Vicente A (2009) Chitosan/clay films' properties as affected by biopolymer and clay micro/nanoparticles' concentrations. Food Hydrocoll., 23: 1895-1902. 
Cha S and Chinnan S. (2004). Biopolymer-based antimicrobial packaging: A Review. Crit. Rev. Food Sci. Nutr., 44: $223-237$.

Chambi H and Grosso C (2006) Edible films produced with gelatin and casein cross-linked with transglutaminase. Food Res. Int., 39: 458-466.

Chen CS, Liau WY and Tsai GJ (1998) Antibacterial effects of N-sulfonated and N-sulfobenzoyl chitosan and application to oyster preservation. J. Food Prot. 61: 1124-1128.

Chen H, Hu X, Chen E, Wu S, McClements J, Liu S, Li B and Li Y (2016) Preparation, characterization, and properties of chitosan films with cinnamaldehyde nanoemulsions. Food Hydrocoll., 61: 662-671.

Chen XG, Zheng L, Wang Z, Lee CY and Park HJ (2002). Molecular affinity and permeability of different molecular weight chitosan membranes. J. Agric. Food Chem. 50: 5915-5918.

Chien PJ, Sheu F and Yang FH (2007) Effects of edible chitosan coating on quality and shelf life of sliced mango fruit. J. Food Eng., 78: 225-229.

Chiumarelli M and Hubinger D (2012) Stability, solubility, mechanical and barrier properties of cassava starch - Carnauba wax edible coatings to preserve fresh-cut apples. Food Hydrocoll., 28: 59-67.

Coma V (2008) Bioactive packaging technologies for extended shelf life of meat-based products. Meat Sci., 78: 90-103.

Coma V, Martial-Gros A, Garreau S, Copinet A, Salin F and Deschamps A (2002) Edible antimicrobial films based on chitosan matrix. J. Food Sci., 67: 1162-1169.

Coma V, Sebti I, Pardon P, Deschamps A and Pichavant FH (2001) Antimicrobial edible packaging based on cellulosic ethers, fatty acids, and nisin incorporation to inhibit Listeria innocua and Staphylococcus aureus. J. Food. Prot., 64: 470-475.

Cuq B, Gontard N and Guilbert S (1998) Proteins as agricultural polymers for packaging production. Cereal Chem., 75: 1-9.

Darmadji P and Izumimoto M. (1994). Effect of chitosan in meat preservation. Meat Sci., 38: 243-254.

Draget I, Moe T, Skjak-Bræk G and Smidsrød O (2016) Alginates from algae. In: Biopolymer (Hofrichter M and Steinbüchel A, eds.). pp.160-289. Wiley-VCH Verlag GmbH \& Co. KGaA, Weinheim.

Durango M, Soares F and Andrade J (2006) Microbiological evaluation of an edible antimicrobial coating on minimally processed carrots. Food Control., 17: 336-341.

Dutta K, Tripathi S, Mehrotra K and Dutta J (2009) Perspectives for chitosan based antimicrobial films in food applications. Food Chem., 114: 1173-1182.

Elsabee Z, Abdou S, Nagy A and Eweis M (2008) Surface modification of polypropylene films by chitosan and chitosan/pectin multilayer. Carbohydr. Polym., 71: 187-195.

Ferreira O, Nunes A, Delgadillo I and Lopes-da-Silva A (2009) Characterization of chitosan-whey protein films at acid pH. Food Res. Int., 42: 807-813.

Gao Z, Fang Y, Cao Y, Liao H, Nishinari K and Phillips O (2017) Hydrocolloid-food component interactions. Food Hydrocoll., 68: 149-156.

Gennadios A, McHugh H, Weller L and Krochta M (1994) Edible coatings and films to improve food quality. In: Edible Coatings and Films to Improve Food Quality (Elizabeth B, Robert H, Jinhe B, eds.). pp.201-277. CRC press. Lancaster.

Ghanbarzadeh B, Musavi M, Oromiehie A, Rezayi K, Rad R and Milani J (2007) Effect of plasticizing sugars on water vapor permeability, surface energy and microstructure properties of zein films. LWT-Food Sci., 40: 1191-1197.

Gómez-Estaca J, López de Lacey A, López-Caballero E, Gómez-Guillén C and Montero P (2010) Biodegradable gelatin-chitosan films incorporated with essential oils as antimicrobial agents for fish preservation. Food Microbiol., 27: 889-896.

Grant T, Morris R, Rees A, Smith J and Thom D (1973) Biological interactions between polysaccharides and divalent cations: the egg-box model. FEBS letters, 32: 195-198.

Guilbert S (1986) Technology and application of edible protective films. In: Food Packaging

Preservation, Theory and Practice (Mathlouthi M, ed.). pp.371-394. Elsevier Applied Science. London.

Ilium L (1998) Chitosan and its use as a pharmaceutical excipient. Pharm. Res., 15: 1326-1331.

Jamilah B and Harvinder K (2002) Properties of gelatins from skins of fish-black tilapia (Oreochromis mossambicus) and red tilapia (Oreochromis nilotica). J. Food Chem., 77: 81-84.

Jiménez A, Fabra J, Talens P and Chiralt, A (2012). Effect of re-crystallization on tensile, optical and water vapour barrier properties of corn starch films containing fatty acids. Food Hydrocoll., 26: 302-310.

Jo C, Lee J, Lee K and Byun M (2001) Quality properties of pork sausage prepared with water-soluble chitosan oligomer. J. Meat Sci., 59: 369-375. 
Jongjareonrak A, Benjakul S, Visessanguan W and Tanaka M (2008) Antioxidative activity and properties of fish skin gelatin films incorporated with BHT and $\alpha$-tocopherol. Food Hydrocoll., 22: 449-458.

Kaewklin P, Siripatrawan U, Suwanagul A and Lee YS (2018) Active packaging from chitosan-titanium dioxide nanocomposite film for prolonging storage life of tomato fruit. Int. J. Biol. Macromol., 112: 523-529.

Kester J and Fennema O (1986). Edible films and coatings: a review. Food Technol., 40: 47-59.

Leceta I, Guerrero P, Ibarburu I, Dueñas T and de la Caba K (2013) Characterization and antimicrobial analysis of chitosan-based films. J. Food Eng., 116: 889-899.

Limpan N, Prodpran T, Benjakul S and Prasarpran S (2010) Properties of biodegradable blend films based on fish myofibrillar protein and polyvinyl alcohol as influenced by blend composition and ph level. J. Food Eng., 100: 85-92.

Liu L, Fishman L, Hicks B, Kende M and Ruthel G (2006) Pectin/zein beads for potential colon-specific drug delivery: synthesis and in vitro evaluation. Drug Deliv., 13: 417-423.

Luo Y and Wang Q (2014) Zein-based micro-and nano-particles for drug and nutrient delivery: A review. J. Appl. Pharm. Sci., 131: $1-12$.

Mali S, Grossmann E, García A, Martino N and Zaritzky E (2004) Barrier, mechanical and optical properties of plasticized yam starch films. Carbohydr. Polym., 56: 129-135.

Mantovan J, Bersaneti T, Faria-Tischer S, Celligoi C and Mali S (2018) Use of microbial levan in edible films based on cassava starch. Food Packaging Shelf., 18: 31-36.

Maqbool M, Ali A, Ramachandran S, Smith R and Alderson G (2010) Control of postharvest anthracnose of banana using a new edible composite coating. Crop Prot., 29: 1136-1141.

Marques M (2014) Enzymes in the dissolution testing of gelatin capsules. AAPS PharmSciTech., 15: 1410-1416.

McHugh H and Krochta M (1994) Sorbitol- vs Glycerol-Plasticized Whey Protein Edible Films: Integrated Oxygen Permeability and Tensile Property Evaluation. J. Agric. Food Chem., 42: 841-845.

Miller K, Chiang M and Krochta J (1997) Heat curing of whey protein films. J. Food Sci., 62: 1189-1193.

Mitani T, Nakajima C, Sungkono E and Ishii H (1995) Effects of ionic strength on the adsorption of heavy metals by swollen chitosan beads. J. Environ. Sci., 30: 669-674.

Mujtaba M, Morsi E, Kerch G, Elsabee Z, Kaya M, Labidi J and Khawar M (2019) Current advancements in chitosan-based film production for food technology; A review. Int. J. Biol. Macromol., 121: 889-904.

Murray A and Dutcher R (2006). Effect of changes in relative humidity and temperature on ultrathin chitosan films. Biomacromolecules., 7: 3460-3465.

Nagahama H, Maeda H, Kashiki T, Jayakumar R, Furuike T and Tamura H (2009) Preparation and characterization of novel chitosan/gelatin membranes using chitosan hydrogel. Carbohydr. Polym., 76: 255-260.

No HK, Park NY, Ho Lee, SH and Meyers P (2002) Antibacterial activity of chitosans and chitosan oligomers with different molecular weights. Int. J. Food Microbiol., 74: 65-72.

Nur Hanani A, Roos H and Kerry P (2014) Use and application of gelatin as potential biodegradable packaging materials for food products. Int. J. of Biol. Macromol., 71: 94-102.

Nurhayati N and Agusman A (2011) Chitosan edible films of shrimp waste as food packaging, friendly packaging. Squalen Bulletin of Marine and Fisheries Postharvest and Biotechnology., 6: 38-44.

Ojagh M, Rezaei M, Razavi H and Hosseini H (2010) Effect of chitosan coatings enriched with cinnamon oil on the quality of refrigerated rainbow trout. Food Chem., 120: 193-198.

Ou S, Wang Y, Tang S, Huang C and Jackson G (2005) Role of ferulic acid in preparing edible films from soy protein isolate. J. Food Eng., 70: 205-210.

Ouattara B, Simard R, Piette G, Begin A and Holley A (2000) Diffusion of acetic and propionic acids from chitosan-based antimicrobial packaging films. Int. J. Food Microbiol., 65: 768-773.

Ozcalik O and Tihminlioglu F (2013) Barrier properties of corn zein nanocomposite coated polypropylene films for food packaging applications. J. Food Eng., 114: 505-513.

Perez-Gago M, Serra M, Alonso M, Mateos M and Río D (2003) Effect of solid content and lipid content of whey protein isolate-beeswax edible coatings on color change of fresh-cut apples. J. Food Sci., 68: 2186-2191.

Pranoto Y, Rakshit K and Salokhe M (2005) Enhancing antimicrobial activity of chitosan films by incorporating garlic oil, potassium sorbate and nisin. LWT - Food Sci. Technol., 38: 859-865. 
Qazanfarzadeh Z and Kadivar M (2016) Properties of whey protein isolate nanocomposite films reinforced with nanocellulose isolated from oat husk. Int. J. Biol. Macromol., 91: 1134-1140.

Rabea I, Badawy T, Stevens V, Smagghe G and Steurbaut W (2003) Chitosan as antimicrobial agent: Applications and mode of action. Biomacromolecules., 4: 1457-1465.

Rathke D and Hudson M (1994) Review of chitin and chitosan as fiber and film formers. J. Macromol. Sci. C., 34: 375-437.

Rhim JW and Ng W (2007) Natural Biopolymer-Based Nanocomposite Films for Packaging Applications. Crib. Rev. Food Sci. Nutr., 47: 411-433.

Sathivel S, Liu Q, Huang J and Prinyawiwatkul W (2007) The influence of chitosan glazing on the quality of skinless pink salmon (Oncorhynchus gorbuscha) fillets during frozen storage. J. Food Eng., 83: 366-373.

Shellhammer T and Krochta J (1997) Whey protein emulsion film performance as affected by lipid type and amount. J. Food Sci., 62: 390-394.

Shukla R and Cheryan M (2001) Zein: the industrial protein from corn. Ind. Crop Prod., 13: 171-192.

Silva D, Cerqueira Â and Vicente A (2012) Nanoemulsions for Food Applications: Development and Characterization. Food Bioproc. Tech., 5: 854-867.

Siripatrawan U and Harte R (2010) Physical properties and antioxidant activity of an active film from chitosan incorporated with green tea extract. Food Hydrocoll., 24: 770-775.

Sobral A, Menegalli C, Hubinger D and Roques A (2001) Mechanical, water vapor barrier and thermal properties of gelatin based edible films. Food Hydrocoll., 15: 423-432.

Sugumar S, Mukherjee A and Chandrasekaran N (2015) Eucalyptus oil nanoemulsion-impregnated chitosan film: antibacterial effects against a clinical pathogen, Staphylococcus aureus, in vitro. Int. J. Nanomed., 10: 67-75.

Suyatma E, Copinet A, Tighzert L and Coma V (2004) Mechanical and Barrier Properties of Biodegradable Films Made from Chitosan and Poly (Lactic Acid) Blends. J. Polym. Environ., 12: 1-6.

Tharanathan N (2003) Biodegradable films and composite coatings: past, present and future. Trends Food Sci. Technol., 14: 71-78.

Thawien B and Manjeet C (2008) Preparation and properties of rice starch chitosan blend biodegradable film. LWT - Food Sci. Technol., 41: 1633-1641.

Tiwary K and Rana V (2010) Cross-linked chitosan films: effect of cross-linking density on swelling parameters. Pak. J. Pharm. Sci., 23: 443-448.

Uchida Y, Izume M and Ohtakara A (1989). Preparation of chitosan. oligomers with purified chitosanase and its application. In: Chitin and chitosan (Skjåk-Braek G, Anthonsen T and Sandford P, eds.). pp.373-382. Elsevier Applied Science. London and New York.

Vargas M, Albors A, Chiralt A and González-Martínez C (2009) Characterization of chitosan-oleic acid composite films. Food Hydrocoll., 23: 536-547.

Vieira A, da Silva A, dos Santos O and Beppu M (2011) Natural-based plasticizers and biopolymer films: A review. Eur. Polym. J., 47: 254-263.

Wang LZ, Liu L, Holmes J, Kerry F, Kerry P (2007) Assessment of film-forming potential and properties of protein and polysaccharide-based biopolymer films. Int. J. Food Sci. Technol., 42: 1128-1138.

Wu T, Zivanovic S, Draughon A, Conway S and Sams, CE (2005) Physicochemical properties and bioactivity of fungal chitin and chitosan. J. Agric. Food Chem., 53: 3888-3894.

Yuan G, Chen X and Li D (2016) Chitosan films and coatings containing essential oils: The antioxidant and antimicrobial activity, and application in food systems. Food Res. Int., 89: 17-128.

Zhang M, Li XH, Gong YD, Zhao NM and Zhang XF (2002) Properties and biocompatibility of chitosan films modified by blending with PEG. Biomaterials., 23: 2641-2648.

Zheng LY and Zhu JF (2003) Study on antimicrobial activity of chitosan with different molecular weights. Carbohydr. Polym., 54: 527-530.

Ziani K, Fernández-Pan I, Royo M and Maté I (2009) Antifungal activity of films and solutions based on chitosan against typical seed fungi. Food Hydrocoll., 23: 2309-2314. 